\title{
Induction motor drive based on direct torque controlled used multi-pulse AC-DC rectifier
}

\author{
Rohollah Abdollahi \\ Department of Electrical Engineering, Technical and Vocational University (Qom Boys Technical College), \\ Qom, Iran
}

\begin{tabular}{|c|c|}
\hline Article Info & ABSTRACT \\
\hline & \multirow{5}{*}{$\begin{array}{l}\text { This paper presents the direct torque-controlled induction motor drives } \\
\text { (DTCIMDs) based on a retrofit 44-pulse rectifier (44PR). A 22-phase } \\
\text { polygon autotransformer (PA) is designed to supply the rectifiers. The above } \\
\text { structure improves the power quality standards in the power grid and } \\
\text { complies with the requirements of the IEEE-519 standard for different loads. } \\
\text { Besides, a power factor close to one is obtained for a wide range of DTCIMD } \\
\text { performance. The results show that the total harmonic distortion (THD) of } \\
\text { the input current under variable loads for 44PR is less than 3\%. }\end{array}$} \\
\hline Received Oct 22, 2019 & \\
\hline Revised Nov 27, 2020 & \\
\hline Accepted Jan 6, 2021 & \\
\hline Keywords: & \\
\hline
\end{tabular}

CIMD

Polygon autotransformer

Power quality

Rectifier with 44-pulse

This is an open access article under the CC BY-SA license.

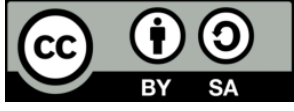

\section{Corresponding Author:}

Rohollah Abdollahi

Department of Electrical Engineering

Technical and Vocational University

Next to the main post office, Shahid Ghoddusi, Qom Province, Iran

Email: rohollah.abdollahi@yahoo.com

\section{INTRODUCTION}

Today, induction motor drive based on direct torque controlled (DTCIMDs) based on 6PR are used in several industrial applications [1]. The most important drawback of a 6PR used in DTCIMDs is the injection of the current harmonic into the grid. The value of current THD should be confined within the IEEE standard 519 [2] and the IEC 61000-3-2 [3]. To this end, researchers have focused on solutions to eliminate current THD such as the use of multipulse rectifiers (MPRs). These MPRs are based on phase-shifting transformers or pulse doubling circuits [4-7]. However, under low source impedance or low load, the current THD for MPRs up to 20 pulses will be more than 5\% [8-14]. A 24PR based on polygon autotransformer has been reported in [15], which has a THD change from FL to LL from $4.48 \%$ to $5.65 \%$. Another 24PR based on $\mathrm{T}$ autotransformer has also been reported in [16], in which current THD is more than 5\% under a light load. It should be noted that some applications, such as sonar applications, require current THD less than 3\%, and therefore the use of MPRs with pulses more than 24 is inevitable [17].

In order to reduce the THD of the ac main current, in [18-24] Authors have provided 20, 30, 36 and 40PRs, but these MPRs have high magnetic rating and high complexity. A 40PR based on T autotransformer has been reported in [25], which has a THD change from full load to light load from $2.55 \%$ to $3.79 \%$. Another 40PR based on topology autotransformer has also been reported in [26], in which current THD is more than $3 \%$ under a light load. However, these topologies have high magnetic ratings and are therefore expensive. 
Increasing the number of pulses reduces the current THD but with the additional complexity and cost of MPRs [27-33]. On the other hand, the use of passive or active filters can also lead to current THD reduction [34-40]. But passive filters lead to additional losses, and their efficiency is strongly influenced by frequency changes. Active filters are also very expensive and have a complex structure. Using MPRs is one of the most suitable methods for current THD reduction. In this paper, a DTCIMD based on 44PR is proposed with a novel polygon autotransformer to current THD reduction, as shown in Figure 1.

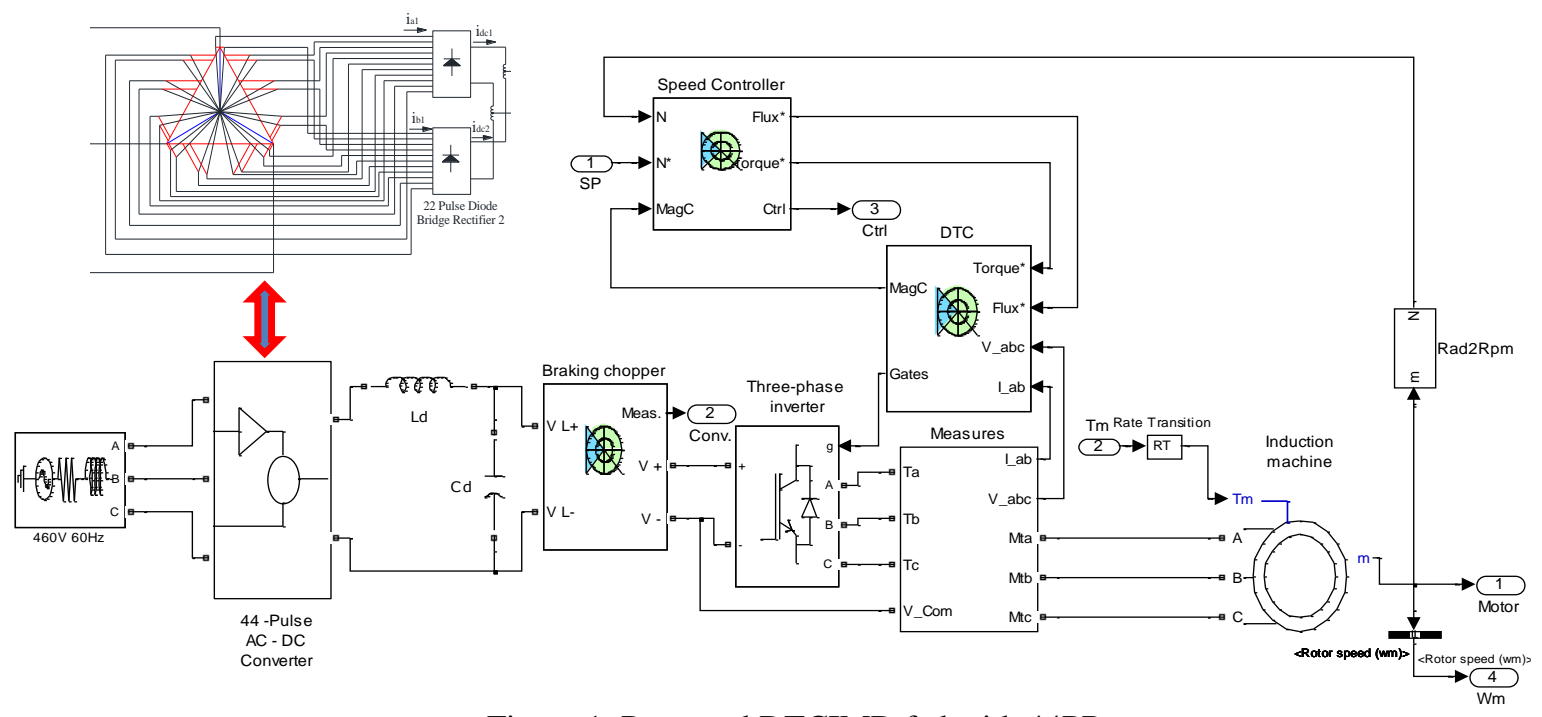

Figure 1. Proposed DTCIMD fed with 44PR

\section{PROPOSED 44PR}

In Figure 1, the DTCIMD fed with 44PR is presented. The proposed 44PR includes two 22PR, and an 11-phase polygon autotransformer, and two IPT. The main task of the autotransformer is to produce two series of 11-phase voltage with a phase shift of 8.18 degrees. However, the main task of the IPT in this configuration is to guarantee that the voltages of the two 11-phase autotransformer's outputs are operating independently. In Figure 2 the phasor diagram of the 11-phase autotransformer for the 28-pulse rectifier is depicted. The harmonics are eliminated with a minimum phase displacement of $8.18^{\circ}$. Two sets of 7 phases with the phase shift of $4.09^{\circ}$ are generated by the 11-phase autotransformers for each bridge. The two sets of the 11-phase autotransformer output voltage are connected to the 22PR. We assume $\left(\mathrm{V}_{\mathrm{a} 1}\right.$ to $\left.\mathrm{V}_{\mathrm{a} 11}\right)$ and $\left(\mathrm{V}_{\mathrm{b} 1}\right.$ to $\mathrm{V}_{\mathrm{b} 11}$ ) for the first and second rectifiers, the three-phase voltages of primary windings and voltage of the 11 phases applied to the windings is assumed to be as follows:

$$
V_{A}=V_{s} \angle 0^{\circ} V_{B}=V_{s} \angle-120^{\circ}, V_{C}=V_{s} \angle 120^{\circ}
$$

Input voltages for two 22PRs are:

$$
\begin{aligned}
& V_{a 1}=V_{s} \angle+4.09^{\circ}, V_{a 2}=V_{s} \angle-28.637^{\circ}, V_{a 3}=V_{s} \angle-61.364^{\circ}, \\
& V_{a 4}=V_{s} \angle-94.091^{\circ}, V_{a 5}=V_{s} \angle-126.818^{\circ}, V_{a 6}=V_{s} \angle-159.545^{\circ}, \\
& V_{a 7}=V_{s} \angle-192.272^{\circ}, V_{a 8}=V_{s} \angle-224.999^{\circ}, V_{a 9}=V_{s} \angle-257.726^{\circ}, V_{a 10}= \\
& V_{s} \angle-290.453^{\circ}, V_{a 11}=V_{s} \angle-323.18^{\circ} . \\
& V_{b 1}=V_{s} \angle-4.09^{\circ}, V_{b 2}=V_{s} \angle-36.817^{\circ}, V_{b 3}=V_{s} \angle-69.544^{\circ}, \\
& V_{b 4}=V_{s} \angle-102.271^{\circ}, V_{b 5}=V_{s} \angle-134.998^{\circ}, V_{b 6}=V_{s} \angle-167.725^{\circ}, \\
& V_{b 7}=V_{s} \angle-200.452^{\circ}, V_{b 8}=V_{s} \angle-233.179^{\circ}, V_{b 9}=V_{s} \angle-265.906^{\circ}, \\
& V_{b 7}=V_{s} \angle-298.633^{\circ}, V_{b 8}=V_{s} \angle-331.36^{\circ} .
\end{aligned}
$$



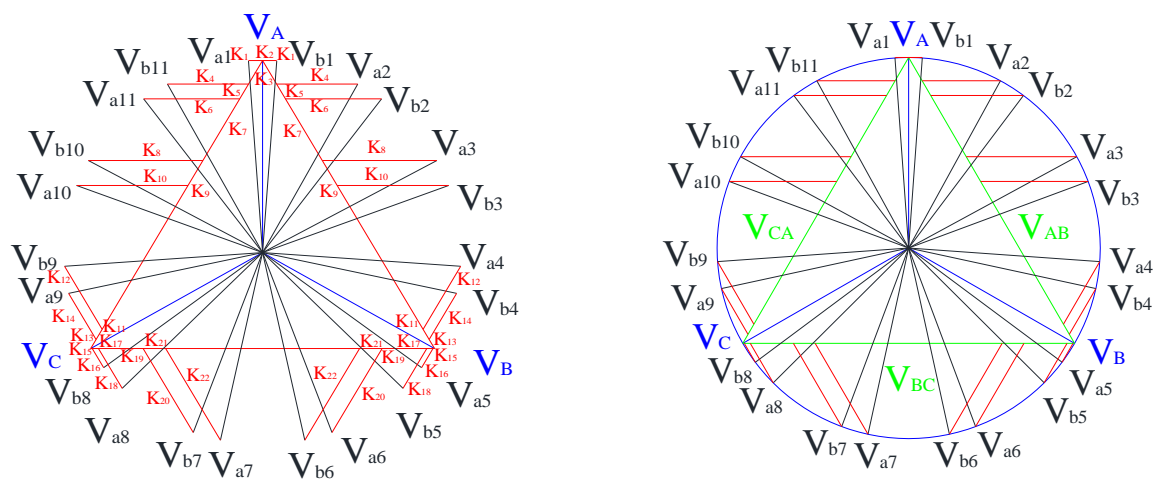

Figure 2. Phasor diagram and representation of 11-phase autotransformer for proposed 44PR

In the 44PR, the output voltage is $20 \%$ higher than the traditional rectifier with six-pulse. Therefore, to use for retrofit applications it is necessary to decline the output voltage to $20 \%$ through the recalculation of the number of winding. Accordingly, the number of turns of the 11-phase autotransformer winding for retrofit applications is modified as $\mathrm{K}_{1}$ to $\mathrm{K}_{22}$ is equal to $0.11,0.09,0.18,0.13,0.22,0.17,0.40,0.21,0.47$, $0.21,0.17,0.12,0.14,0.07,0.11,0.01,0.13,0.05,0.24,0.18,0.29$, and 0.20 .

\section{SIMULATION USING MATLAB/SIMULINK}

The multi-winding transformer block in Simulink/Matlab software is utilized to evaluate the performance of the proposed 44PR configuration as shown in Figure 3. The three-phase input voltage' value is $460 / 60 \mathrm{~Hz}$ and the motor is 4-pole and $50 \mathrm{hp}$. Also, detailed information on DTCIMD is listed in the appendix.

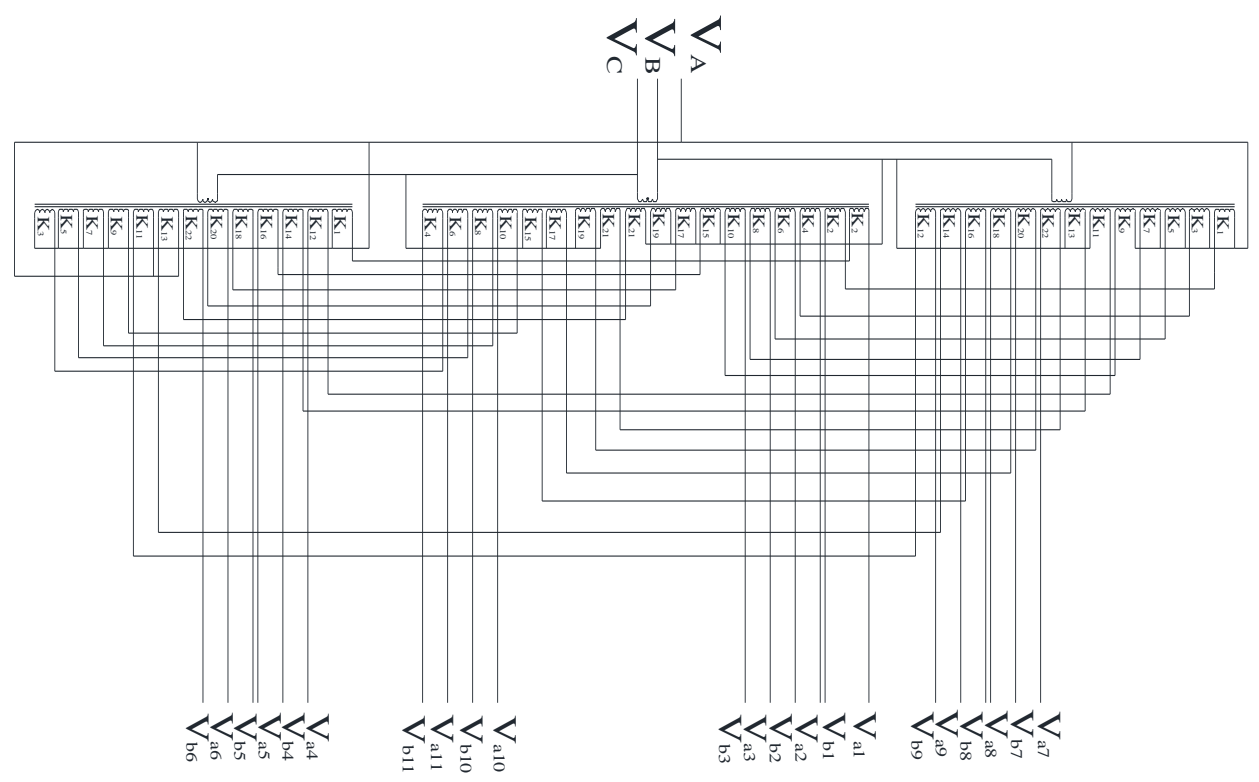

Figure 3. Simulink model of proposed 11-phase autotransformer winding

\section{STUDY VALIDATION}

The 44PR Simulink diagram is shown in Figure 4. The simulation results are shown in Figures 5-9. The output voltage of the 11-phase autotransformer with an $8.18^{\circ}$ phase shift is shown in Figure 5(a). The 44PR output voltage is shown in Figure 5(b). It should be noted that this 44PR is suitable for retrofit applications. Because the average output voltage of the proposed 44PR is $609 \mathrm{~V}$, and is equal to the average output voltage of a 6PR $(608 \mathrm{~V})$. The dynamic response of DTCIMD based on 6PR and proposed 44PR are 
shown in Figures 6(a)-(b) respectively. The input current and harmonic FFT of 6PR and 44PR are shown in Figures 7-8, respectively to check their compliance with the standard limitations. Finally, the 44PR offers excellent performance in improving power quality indicators under FL and LL conditions.

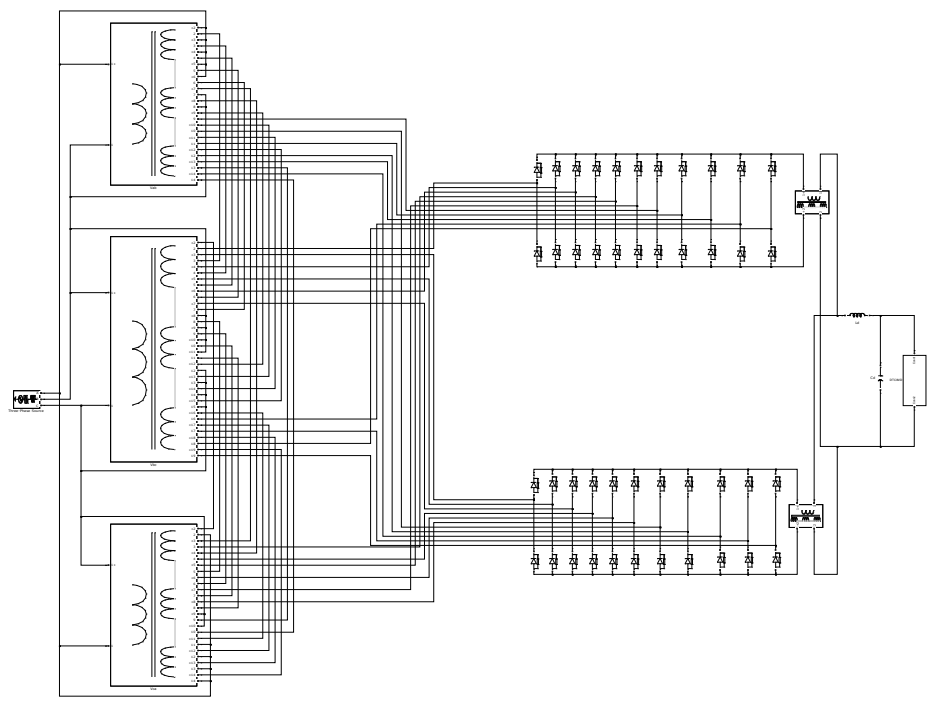

Figures 4. The Simulink 44PR block diagram

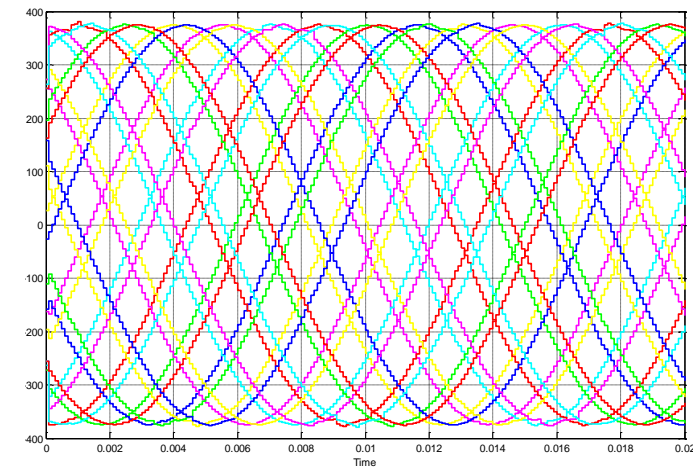

(a)

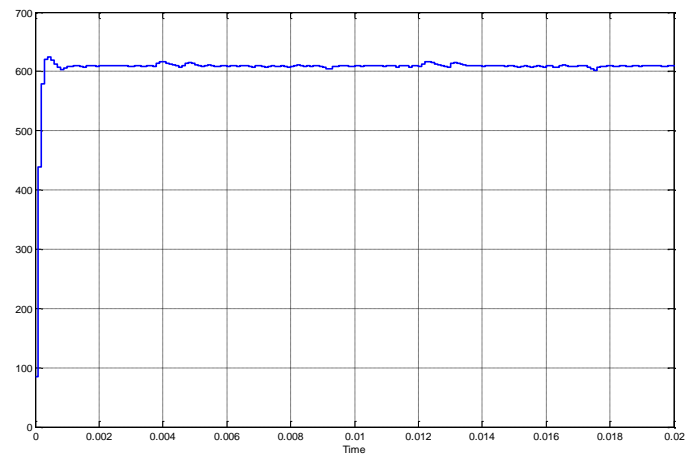

(b)

Figure 5. The output voltage of, (a) 11-phase autotransformer, (b) 44PR

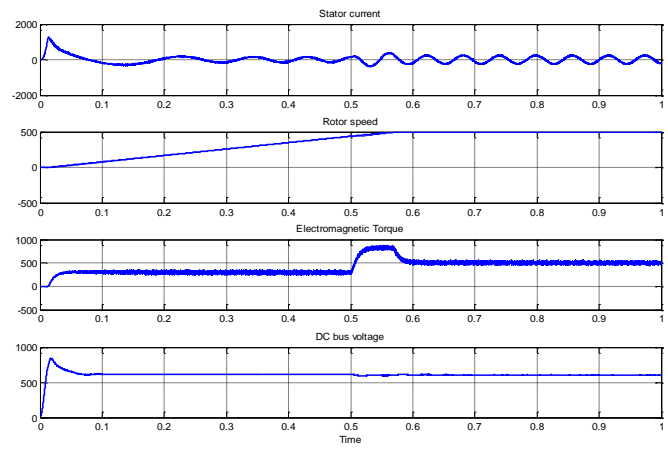

(a)

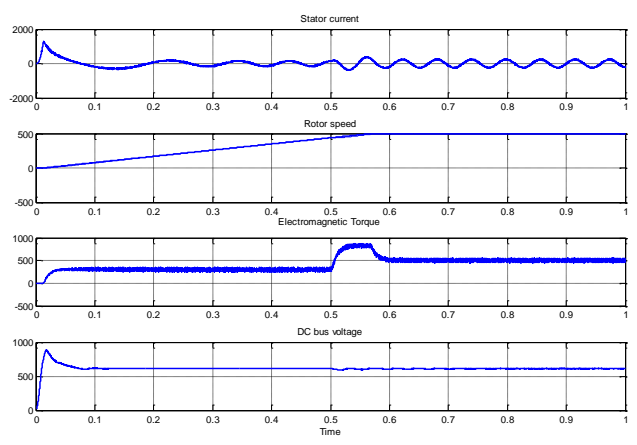

(b)

Figure 6. Dynamic response of DTCIMD based on, (a) 6PR, (b) Proposed 44PR 
As shown in Figure 7, the current THD of the 6PR is very high, equal to $28.53 \%$ at full load (FL) and 52.52\% at light load (LL), which is outside the standard limit. As shown in Figure 8, in proposed 44PR, at FL the current THD is $1.89 \%$ and the power factor is 0.9971 , and at LL, the THD current is $2.97 \%$ and the power factor is 0.9965 . This confirms that the current THD proposed 44PR is always less than $3 \%$ and is suitable for sonar applications. The power quality indicators for 6PR, 40PR [25], 40PR [26], and 44PR are listed in Table 1. The 40PR based on $\mathrm{T}$ and polygon autotransformer for reducing current THD has been reported in [25] and [26] respectively. But in these topologies under light load conditions, the current THD is more than $3 \%$.
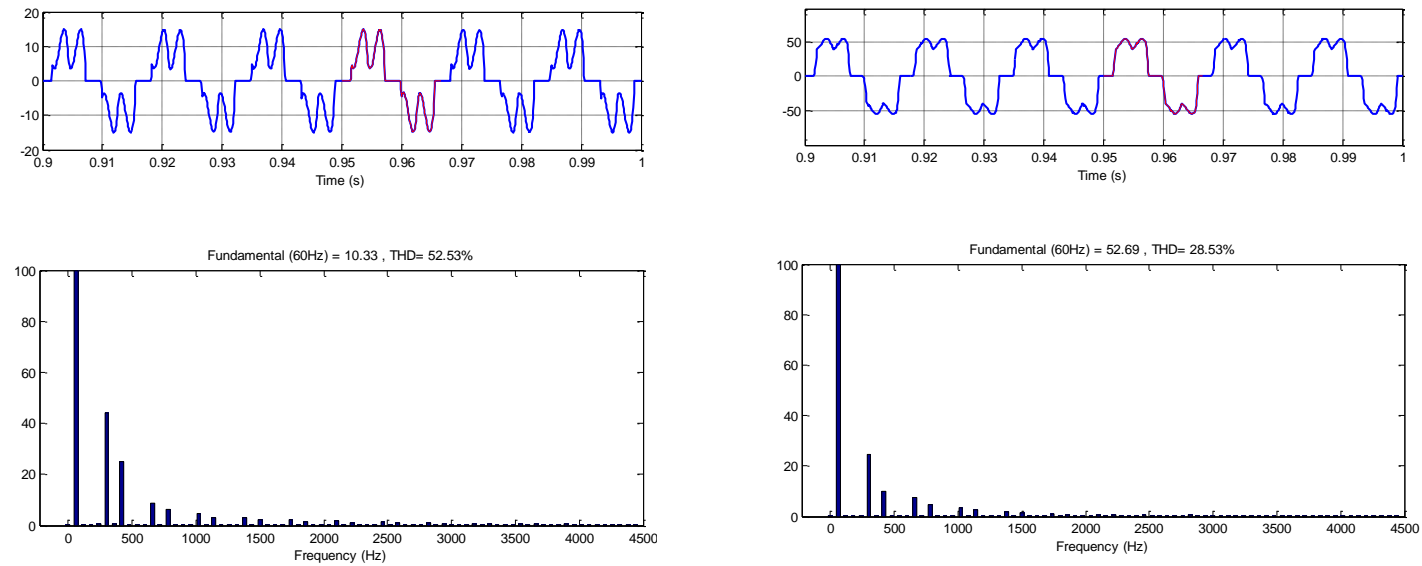

(a)

(b)

Figure 7. The input current and harmonic FFT of 6PR, (a) under light, (b) full light
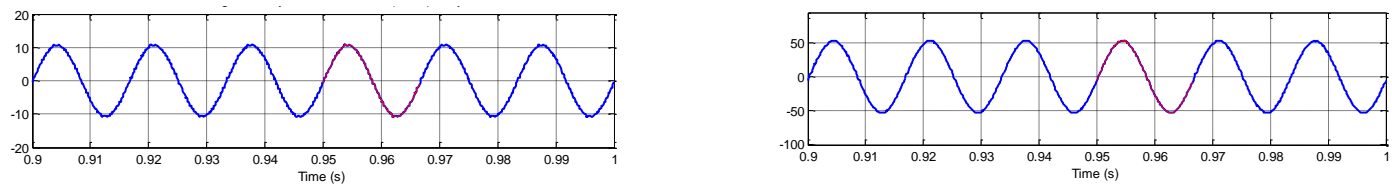

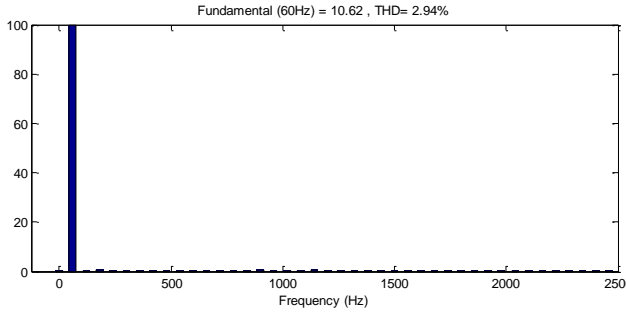

(a)

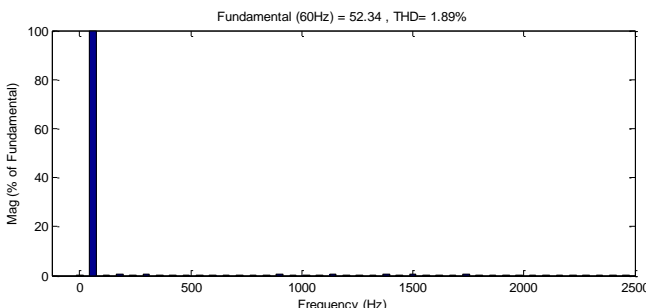

(b)

Figure 8. The input current and harmonic FFT of 44PR under (a) under light, (b) full light

Table 1. Evaluation of power quality indicators from DTCIMD fed with 6PR, 40PR [25], 40PR [26], and proposed 44PR

\begin{tabular}{|c|c|c|c|c|c|c|c|c|c|c|c|c|c|}
\hline \multirow{3}{*}{ No } & \multirow{3}{*}{ Structured } & \multirow{3}{*}{$\begin{array}{l}\% \mathrm{THD} \\
\text { of } \mathrm{AC} \\
\text { voltage }\end{array}$} & \multirow{3}{*}{$\begin{array}{l}\text { AC } \\
\text { current } \\
\text { (A) } \\
\text { Light } \\
\text { load }\end{array}$} & \multirow{2}{*}{\multicolumn{2}{|c|}{$\begin{array}{l}\% \mathrm{THD} \text { of } \mathrm{AC} \\
\text { current }\end{array}$}} & \multirow{2}{*}{\multicolumn{2}{|c|}{$\begin{array}{l}\text { Distortion } \\
\text { factor }\end{array}$}} & \multirow{2}{*}{\multicolumn{2}{|c|}{$\begin{array}{l}\text { Displacement } \\
\text { factor }\end{array}$}} & \multirow{2}{*}{\multicolumn{2}{|c|}{ Power factor }} & \multirow{2}{*}{\multicolumn{2}{|c|}{ DC voltage }} \\
\hline & & & & & & & & & & & & & \\
\hline & & & & $\begin{array}{l}\text { Full } \\
\text { load }\end{array}$ & $\begin{array}{l}\text { Light } \\
\text { load }\end{array}$ & $\begin{array}{l}\text { Light } \\
\text { load }\end{array}$ & $\begin{array}{l}\text { Full } \\
\text { load }\end{array}$ & $\begin{array}{l}\text { Light } \\
\text { load }\end{array}$ & $\begin{array}{l}\text { Full } \\
\text { load }\end{array}$ & $\begin{array}{l}\text { Light } \\
\text { load }\end{array}$ & $\begin{array}{l}\text { Full } \\
\text { load }\end{array}$ & $\begin{array}{l}\text { Light } \\
\text { load }\end{array}$ & $\begin{array}{l}\text { Full } \\
\text { load }\end{array}$ \\
\hline 1 & 6PR & 5.63 & 10.25 & 52.56 & 52.80 & 28.52 & 0.959 & 0.985 & 0.988 & 0.872 & 0.948 & 616.6 & 607.9 \\
\hline 2 & 40PR [25] & 2.57 & 10.51 & 52.59 & 3.79 & 2.55 & 0.999 & 0.999 & 0.999 & 0.998 & 0.998 & 610.5 & 607.5 \\
\hline 3 & 40PR [26] & 3.138 & 10.51 & 52.59 & 3.851 & 2.226 & 0.999 & 0.997 & 0.999 & 0.998 & 0.998 & 695.3 & 680.5 \\
\hline 4 & $\begin{array}{l}\text { Proposed } \\
\text { 44PR }\end{array}$ & 1.68 & 10.62 & 53.34 & 2.94 & 1.89 & 0.999 & 0.997 & 0.997 & 0.996 & 0.997 & 613.1 & 609.1 \\
\hline
\end{tabular}


Table 2 shows the effect of the load change on different power quality indicators. Also, the current THD and power factor variation for 6PR and 44PR are shown in the Figure 9. The results show that under different load conditions, the current THD is always less than $3 \%$ and the power factor is always higher than 0.99 for the proposed 44PR.

Table 2. The effect of load change on power quality indices of proposed PR

\begin{tabular}{lllllllll}
\hline Load (\%) & \multicolumn{2}{l}{ THD $(\%)$} & CF of Is & DF & DPF & PF & RF $(\%)$ & Vdc (V) \\
& Is & Vs & & & & & & \\
\hline 20 & 2.94 & 0.72 & 1.413 & 0.9987 & 0.9978 & 0.9965 & 0.002 & 613 \\
40 & 2.44 & 1.08 & 1.413 & 0.9994 & 0.9977 & 0.9971 & 0.003 & 612 \\
60 & 2.20 & 1.27 & 1.414 & 0.9996 & 0.9976 & 0.9972 & 0.005 & 611 \\
80 & 2.03 & 1.51 & 1.414 & 0.9997 & 0.9974 & 0.9971 & 0.002 & 610 \\
100 & 1.89 & 1.68 & 1.414 & 0.9997 & 0.9974 & 0.9971 & 0.005 & 609 \\
\hline
\end{tabular}

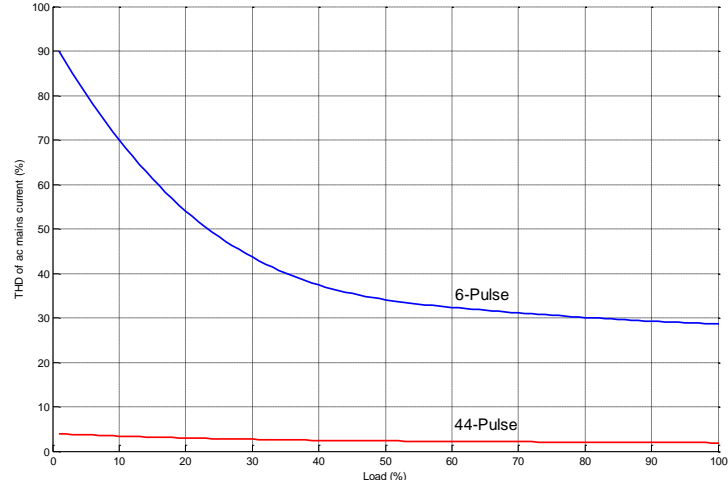

(a)

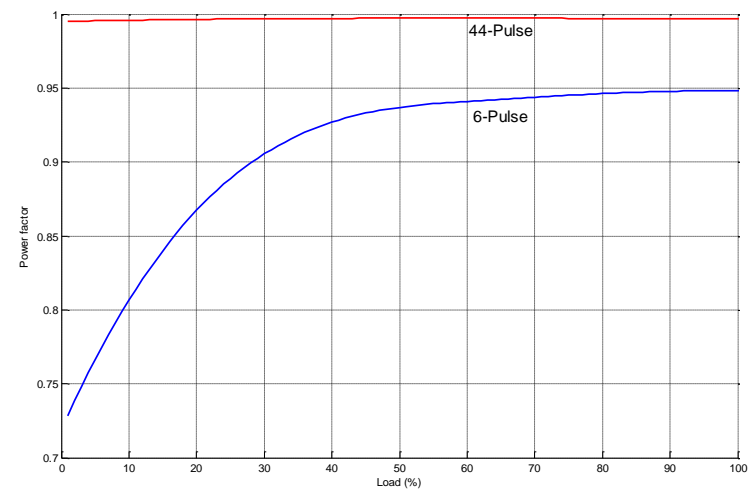

(b)

Figure 9. (a) The current THD, (b) Power factor variation for 6PR and 44PR

The kVA rating of the components in the 44PR is calculated as [4]:

$$
k V A=0.5 \sum V_{\text {winding }} I_{\text {winding }}
$$

where $V_{\text {winding }}$ and $I_{\text {winding }}$ indicate the full load voltage and current of the winding. The kVA ratings of the 11phase autotransformer and interphase transformer (IPT) are $42.57 \%$ and $0.45 \%$ of the load rating. It should be noted that to current THD <3\%, the 44PR requires $43.02 \%$ of the load rating. This rating is lower than many other MPRs. Table 3 shows a comparison of the 44PR with the 40PR [25] and the 40PR [26] in terms of the kVA rating and the price of the. The estimated price is 5 times the kVA rating of the autotransformer. The results show that the proposed 44PR costs less than 40PRs [25-26]. Also, at full load, the efficiency of the proposed 44PR is $97.8 \%$.

Table 3. Comparison of kVA rating and cost in 40PR [24], 40PR [25], and proposed 44PR

\begin{tabular}{|c|c|c|c|c|c|c|}
\hline System configuration & $\begin{array}{l}\text { Magnetic ratings } \\
\mathrm{kVA} \text { rating of } \\
\text { autotransformer } \\
(\% \text { of load })\end{array}$ & $\begin{array}{l}\text { ZSBT kVA } \\
\text { rating }\end{array}$ & $\begin{array}{l}\text { IPT kVA } \\
\text { rating }\end{array}$ & $\begin{array}{l}\text { Sum kVA } \\
\text { rating }\end{array}$ & $\begin{array}{l}\text { Diodes } \\
\text { number }\end{array}$ & Estimated price (\$) \\
\hline 40PR [24] & 61.29 & 2.15 & 0.54 & 63.98 & 42 & 413.56 \\
\hline 40PR [25] & 53.72 & 2.83 & 0.71 & 57.26 & 42 & 379.96 \\
\hline Proposed 44PR & 42.57 & - & 0.45 & 43.02 & 44 & 310.99 \\
\hline
\end{tabular}

\section{CONCLUSION}

This paper presents a DTCIMD based on 44PR. The 44PR consists of an 11-phase retrofit autotransformer. The results show that the current THD at various load is less than $3 \%$ and the power factor is higher than $99 \%$. Also, the $\mathrm{kVA}$ rate and the cost of the proposed 44PR are lower than similar MPRs. In 
summary, reducing the input current THD, increasing the power factor along with the lower kVA rate and lower cost are the main advantages of the proposed 44PR.

\section{APPENDIX}

DTCIMD Specifications

Source impedance : $\mathrm{Z}_{\mathrm{s}}=3 \%$.

Induction motor $: \mathrm{R}_{\mathrm{s}}=0.0148 \Omega ; \mathrm{R}_{\mathrm{r}}=0.0092 \Omega ; \mathrm{X}_{\mathrm{ls}}=1.14 \Omega ; \mathrm{X}_{\mathrm{lr}}=1.14 \Omega, \mathrm{X}_{\mathrm{Lm}}=3.94 \Omega, \mathrm{J}=3.1 \mathrm{Kg} \cdot \mathrm{m}^{2}$.

Controller $\quad: \mathrm{K}_{\mathrm{i}}=2000, \mathrm{~K}_{\mathrm{p}}=300$.

DC link $\quad: \mathrm{C}_{\mathrm{d}}=3200 \mu \mathrm{F}, \mathrm{L}_{\mathrm{d}}=2 \mathrm{mH}$.

\section{REFERENCE}

[1] B. K. Bose, "Modern Power Electronics and AC Drives," Singapore: Pearson Education, 1998.

[2] IEEE Standard 519-1992, "IEEE recommended practices and requirements for harmonic control in electrical power systems," New York: IEEE Inc., 1992.

[3] IEC Standard 61000-3-2:2004, "Limits for harmonic current emissions," International Electromechanical Commission, 2004.

[4] D. A. Paice, "Power electronic converter harmonics: multipulse methods for clean power," New York: IEEE Press, 1996.

[5] R. Abdollahi and A. Jalilian, "Application of pulse doubling in star-connected autotransformer based 12-pulse ACDC converter for power quality improvement," International Journal of Electrical and Electronics Engineering, vol. 5, no. 4, pp. 280-288, 2011.

[6] D. A. Paice, "Fifteen-phase autotransformer," U. S. Patent 7719858, May 2010.

[7] B. Singh, S. Gairola, B. N. Singh, A. Chandra, and K. Al-Haddad, "Multipulse AC-DC converters for improving power quality: A review," IEEE Transactions on Power Electronics, vol. 23, no. 1, pp. 260-281, Jan. 2008.

[8] B. Singh, G. Bhuvaneswari, and V. Garg, "Harmonic mitigation using12-pulse AC-DC converter in vectorcontrolled induction motor drives," IEEE Trans. Power Delivery, vol. 21, no. 3, pp. 1483-1492, Jul. 2006.

[9] S. Choi, P. N. Enjeti, H. H. Lee, and I. J. Pitel, "A new active interphase reactor for 12-pulse rectifiers provides clean power utility interface," IEEE Trans. Ind. Appl., vol. 32, no. 6, pp. 1304-1311, 1996.

[10] F. J. Chivite-Zabalza, A. J. Forsyth, and D. R. Trainer, "Analysis and practical evaluation of an 18-pulse rectifier for aerospace applications,” Proc. 2nd Int. Conf. Power Electron. Mach.Drives (PEMD), vol. 1, pp. 338-343, 2004.

[11] B. Singh, G. Bhuvaneswari, and V. Garg, "Harmonic mitigation in AC-DC converters for vector-controlled induction motor drives," IEEE Transactions on Energy Conversion, vol. 22, no. 3, pp. 637-646, Sept. 2007.

[12] R. Abdollahi, "Design and experimental verification of 20-Pulse AC-DC converter for retrofit applications and harmonic mitigation," Journal of Circuits, Systems and Computers, vol. 26, no. 10, pp. 1750147, 2017, doi: 10.1142/S021812661750147X.

[13] B. Singh, G. Bhuvaneswari, and V. Garg, "A novel polygon based 18-pulse AC-DC converter for vector-controlled induction motor drives," IEEE Transactions on Power Electronics, vol. 22, no. 2, Mar. 2007.

[14] B. Singh, V. Garg, and G. Bhuvaneswari, "A novel T-connected autotransformer-based 18-Pulse AC-DC converter for harmonic mitigation in adjustable-speed induction-motor drives," IEEE Transactions on Industrial Electronics, vol. 54, no. 5, pp. 2500-2511, Oct. 2007.

[15] B. Singh, V. Garg, and G. Bhuvaneswari, "Polygon-connected autotransformer-based 24-pulse AC-DC converter for vector-controlled induction-motor drives," IEEE Transactions on Industrial Electronics, vol. 55, no. 1, pp. $197-$ 208, Jan. 2008.

[16] B. Singh, G. Bhuvaneswari, and V. Garg, "T-connected autotransformer-based 24-pulse AC-DC converter for variable frequency induction motor drives," IEEE Transactions on Energy Conversion, vol. 21, no. 3, pp. 663- 672, Sept. 2006

[17] R. Hammond, L. Johnson, A. Shimp, and D. Harder, "Magnetic solutions to line current harmonic reduction," Proc. Conf. Power-Con., pp. 354-364, 1994.

[18] S. Prakash, R. Kalpana, B. Singh, and G. Bhuvaneswari, "A 20-pulse asymmetric multiphase staggering autoconfigured transformer for power quality improvement," IEEE Trans. on Power Electron., vol. 33, no. 2, pp. 917-925, Feb. 2018.

[19] B. Singh, G. Bhuvaneswari, and V. Garg, "An improved power-quality 30-pulse AC-DC for varying loads," IEEE Trans. on Power Delivery, vol. 22, no. 2, pp. 1179-1187, Apr. 2006.

[20] Ch. Xiao-Qiang, H. Chun-Ling, Q. Hao, and L. Min, "Thirty-six pulse rectifier scheme based on zigzag autoconnected transformer," Archives of Electrical Engineering, vol. 65, no. 1, pp. 117-132, Mar. 2016.

[21] B. Singh and S. Gairola, "Design and development of a 36-pulse AC-DC converter for vector-controlled induction motor drive," Proc. IEEE Conf. Power Electron. Drives Syst. PEDS'07, 2007.

[22] Y. Lian, Sh. Yang, H. Ben, and W. Yang, "A 36-pulse diode rectifier with an unconventional interphase reactor," Energies, vol. 12, no. 5, 2019, doi: 10.3390/en12050820.

[23] I. Araujo-Vargas, A. J. Forsyth, and F. J. Chivite-Zabalza, "Capacitor voltage-balancing techniques for a multipulse rectifier with active injection," IEEE Trans. on Ind. Appl., vol. 47, no. 1, pp. 185-198, Jan.-Feb. 2011.

[24] R. Abdollahi, "T-connected autotransformer-based 40-pulse AC-DC converter for power quality improvement," Patent 8982595, Mar. 2015. 
[25] R. Abdollahi, and G. B. Gharehpetian, "Inclusive design and implementation of novel 40-pulse AC-DC converter for retrofit applications and harmonic mitigation," IEEE Transactions on Industrial Electronics, vol. 63, no. 2, pp.667-677, Feb. 2016.

[26] B. Singh and S. Gairola, "A 40-pulse AC-DC converter fed vector-controlled induction motor drive," IEEE Trans. Energy Conv, vol. 23, no. 2, pp.403-411, Jun. 2008.

[27] R. Abdollahi, "Reduced rating 30-pulse AC-DC converter for power quality improvement," International Journal of Applied Power Engineering (IJAPE), vol. 6, no. 3, pp. 205-217, 2017.

[28] R. Abdollahi, "A novel delta/hexagon-connected transformer-based 72-pulse AC-DC converter for power quality improvement," World Applied Sciences Journal, vol. 23, no. 3, pp. 390-401, 2013.

[29] R. Abdollahi, "Harmonic reduction using a novel multipulse AC-DC converter," World Journal of Engineering, vol. 15, no. 4, pp. 520-530, 2018.

[30] F. Meng, W. Yang, Y. Zhu, L. Gao, and S. Yang, "Load adaptability of active harmonic reduction for 12-pulse diode bridge rectifier with active interphase reactor," IEEE Trans. on Power Electron, vol. 30, no. 12, pp. 71707180, Dec. 2015.

[31] R. Abdollahi, "Tapped delta autotransformer based 40-pulse AC-DC converter with reduced kilovolt-ampere (Kva) rating for power quality improvement," Science International (Lahore), vol. 26, no. 4, pp. 1871-1878, 2014.

[32] R. Abdollahi, "A simple harmonic reduction method in 20-pulse AC-DC converter," Journal of Circuits, Systems and Computers, vol. 28, no. 1, pp. 1950013, 2019.

[33] C. M. Young, S. F. Wu, W. S. Yeh, and C. W. Yeh, "A DC-side current injection method for improving AC line condition applied in the 18-pulse converter system," IEEE Trans. on Power Electron., vol. 29, no. 1, pp. 99-109, Jan. 2014.

[34] T. Rajesh and A. Nirmalkumar, "A shunt active power filter for 12 pulse converter using source current detection approach," International Journal of Power Electronics and Drive System (IJPEDS), vol. 7, no. 1, pp. 225-234, Mar. 2016.

[35] N. M. Nordin, et al., "Constant frequency torque controller for DTC with multilevel inverter of induction machines," International Journal of Power Electronics and Drive System (IJPEDS), vol. 7, no. 1, pp. 28-44, Mar. 2016.

[36] K. V. Bindu, R. B. Justus, “A novel power factor correction rectifier for enhancing power quality," International Journal of Power Electronics and Drive System (IJPEDS), vol. 6, no. 4, pp. 772-780, Dec. 2015.

[37] R. Balasubramanian, S. Palani, "Simulation and performance evaluation of shunt hybrid power filter for power quality improvement using pq theory," International Journal of Electrical and Computer Engineering (IJECE), vol. 6, no. 6, pp. 2603-2609, Dec. 2016.

[38] M. Tamilvani, K. Nithya, and M. Srinivasan, "Harmonic reduction in variable frequency drives using active power filter," TELKOMNIKA Telecommunication Computing Electronics and Control, vol. 12, no. 8, pp. 5758-5765, Aug. 2014.

[39] A. Amirullah, O. Penangsang, and A. Soeprijanto, "Power quality analysis of integration photovoltaic generator to three phase grid under variable solar irradiance level," TELKOMNIKA Telecommunication Computing Electronics and Control, vol. 14, no. 1, pp. 29-38, Mar. 2016.

[40] M. Tamilvani, K. Nithya, M. Srinivasan, and S. U. Prabha, "Harmonic reduction in variable frequency drives using active power filter," Buletin Teknik Elektro dan Informatika (Bulletin of Electrical Engineering and Informatics), vol. 3, no. 2, pp. 119-126, Jun. 2014. 